\title{
Lead-Tolerant Bacillus Strains Promote Growth and Antioxidant Activities of Spinach (Spinacia oleracea) Treated with Sewage Water
}

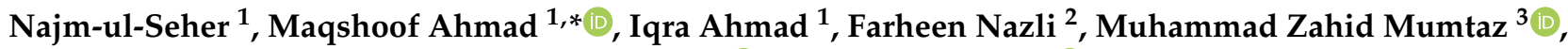 \\ Muhammad Latif ${ }^{4}$, Mobarak S. Al-Mosallam ${ }^{5, *} \mathbb{D}$, Fahad S. Alotaibi ${ }^{5} \mathbb{D}$, Ahmed Z. Dewidar ${ }^{6, *}$, \\ Mohamed A. Mattar 6,7,8(D) and Ahmed A. El-Shafei 6,7,9 (D)
}

Citation: Najm-ul-Seher; Ahmad, M.; Ahmad, I.; Nazli, F.; Mumtaz, M.Z.; Latif, M.; Al-Mosallam, M.S.; Alotaibi, F.S.; Dewidar, A.Z.; Mattar, M.A.; et al. Lead-Tolerant Bacillus Strains Promote Growth and Antioxidant Activities of Spinach (Spinacia oleracea) Treated with Sewage Water. Agronomy 2021, 11, 2482. https:// doi.org/10.3390/agronomy11122482

Academic Editors: Jesus Ochoa and María José Gómez-Bellot

Received: 11 October 2021

Accepted: 3 December 2021

Published: 7 December 2021

Publisher's Note: MDPI stays neutra with regard to jurisdictional claims in published maps and institutional affiliations.

Copyright: (c) 2021 by the authors. Licensee MDPI, Basel, Switzerland. This article is an open access article distributed under the terms and conditions of the Creative Commons Attribution (CC BY) license (https:// creativecommons.org/licenses/by/ $4.0 /)$
1 Department of Soil Science, The Islamia University of Bahawalpur, Bahawalpur 63100, Pakistan; najm.seher@gmail.com (N.-u.-S.); iqra.iqrar@gmail.com (I.A.)

2 Pesticide Quality Control Laboratory, Punjab Agriculture Department, Government of Punjab, Bahawalpur 63100, Pakistan; farheenmaqshoof@gmail.com

3 Institute of Molecular Biology and Biotechnology, Main Campus, The University of Lahore, Lahore 54000, Pakistan; zahidses@gmail.com

4 Department of Agronomy, The Islamia University of Bahawalpur, Bahawalpur 63100, Pakistan; m.latif@iub.edu.pk

5 King Abdulaziz City for Science and Technology (KACST), King Abdullah Road, Riyadh 11442, Saudi Arabia falotaibi@kacst.edu.sa

6 Prince Sultan Bin Abdulaziz International Prize for Water Chair, Prince Sultan Institute for Environmental, Water and Desert Research, King Saud University, P.O. Box 2454, Riyadh 11451, Saudi Arabia; mmattar@ksu.edu.sa (M.A.M.); aelshafei1bn.c@ksu.edu.sa (A.A.E.-S.)

7 Department of Agricultural Engineering, College of Food and Agriculture Sciences, King Saud University, Riyadh 11451, Saudi Arabia

8 Agricultural Engineering Research Institute (AEnRI), Agricultural Research Centre, Giza 12618, Egypt

9 Department of Agricultural Engineering, Faculty of Agriculture (El-Shatby), Alexandria University, Alexandria 21545, Egypt

* Correspondence: maqshoof_ahmad@yahoo.com (M.A.); malmosallam@kacst.edu.sa (M.S.A.-M.); adewidar@ksu.edu.sa (A.Z.D.)

Abstract: Irrigation with sewage-contaminated water poses a serious threat to food security, particularly in developing countries. Heavy metal tolerant bacteria are sustainable alternatives for the removal of wastewater contaminants. In the present study, four lead (Pb)-tolerant strains viz. Bacillus megaterium (N8), Bacillus safensis (N11), Bacillus sp. (N18), and Bacillus megaterium (N29) were inoculated in spinach and grown in sewage water treated earthen pots separately and in combination with canal water. Results showed that $\mathrm{Pb}$-tolerant strains significantly improved plant growth and antioxidant activities in spinach and reduces metal concentration in roots and leaves of spinach plants irrigated with treated wastewater. Strain Bacillus sp. (N18) followed by B. safensis (N11) caused the maximum increase in shoot length, root length, shoot fresh weight, root fresh weight, shoot dry weight, root dry weight, and leaf area compared to the uninoculated control of sewage water treated plants. These strains also improved antioxidant enzymatic activity including catalase, guaiacol peroxidase dismutase, superoxide dismutase, and peroxidases activities compared to the uninoculated control under sewage water conditions. Strain Bacillus sp. (N18) followed by B. safensis (N11) showed the highest reduction in nickel, cadmium, chromium, and Pb contents in roots and leaves of spinach compared to the uninoculated control plants treated with the sewage water. Such potential Pb-tolerant Bacillus strains could be recommended for the growth promotion of spinach after extensive evaluation under field conditions contaminated with wastewater.

Keywords: antioxidant activities; Bacillus spp.; heavy metals tolerance; lead-tolerant bacteria; Spinacia oleracea; wastewater 


\section{Introduction}

Irrigation with sewage wastewater is a common practice in rural and urban areas of the majority of emerging countries. Natural water resources for irrigation have been diminishing due to diverse human activities. In these areas, polluted water is often the only supply of water for irrigation. Yet small farmers often prefer wastewater where other water sources are also available because wastewater has high nutrient and organic matter content that may reduce the need for other costly chemical fertilizers [1]. Irrigation with treated wastewater can have several benefits and environmental applications if appropriately planned, implemented, and managed [2]. Farmers often depend on unprocessed wastewater collection because they do not have an alternative irrigation source $[3,4]$. The application of untreated wastewater in agriculture creates key risks to the health of the community due to chemical and microbial contaminants. It can produce ecological risks in terms of soil and groundwater contamination. It also causes the accumulation of metals in various crops and vegetables [5]. The sewage sludge contains moderate to toxic concentrations of metals including zinc $(\mathrm{Zn})$, copper $(\mathrm{Cu})$, mercury, chromium $(\mathrm{Cr})$, cadmium $(\mathrm{Cd})$, nickel $(\mathrm{Ni})$, and lead $(\mathrm{Pb})[6]$.

The heavy metals exposure to humans has been increased through anthropogenic activities and industrialization that are affecting millions of people around the world through contaminating food [7]. The metals present in the environment may frequently react with biological systems due to their redox reaction and produced metals cations that have an affinity to the nucleophilic sites of vital macromolecules [8]. Heavy metals imposed severe to chronic toxic on various body organs including gastrointestinal, kidney, nervous system, skin, vascular muscle, immune system, and even cause birth defects and cancer [9]. The combined effect of multiple metals on humans may arise complex regimes of stress [10]. Severe complications including abdominal colic pain, bloody diarrhea, and kidney failure were observed due to high doses of heavy metals while low dose exposure causes hidden threats that could be diagnosed in terms of fatigue, anxiety, neuropsychiatric disorders [11]. In addition to heavy metals, microbiological contamination either from animal or human fecal waster are also capable of causing diseases in humans [12].

The wastewater could be treated through biological or chemical means [13]. Biological treatment of wastewater involved the application of naturally occurring microorganisms that are capable to convert dissolved organic matter into dense biomass which can be removed by sedimentation. Microorganisms are commonly used for the efficient removal of toxic metal compounds. Among heavy metals, lead $(\mathrm{Pb})$ is considered the second most toxic metal after arsenic [14]. Lead toxicity inhibited plant growth by negatively affecting the physiological traits of plants $[15,16]$. The $\mathrm{Pb}$ concentration has been reported up to $25.04 \mathrm{mg} \mathrm{kg}^{-1}$ in vegetables treated with sewage water [17]. The Pb-tolerant plant growthpromoting bacteria (PGPB) isolated from $\mathrm{Pb}$-contaminated soil are commonly involved in the bioremediation of $\mathrm{Pb}$ and improved plant growth [18]. Saleem et al. [19] reported that $\mathrm{Pb}$-tolerant bacterial strains improved plant growth and physiology, antioxidative enzymatic activities, and proline contents, and reduce malondialdehyde contents in plants treated with $\mathrm{Pb}$-contamination. Rodríguez-Sánchez et al. [20] reported Pb-tolerance in seven strains of Staphylococcus and Bacillus spp. through biosorption or complexation of $\mathrm{Pb}$-ions as inorganic phosphates.

The heavy metal-tolerant bacteria adopted several mechanisms including biosorption of metal on the cell surface, production of extracellular polymeric substances and metaldetoxifying siderophores, formation of poorly soluble metal precipitates in the form of carbonates, sulfide, and phosphates, and intracellular accumulation to metals [20-23]. The heavy metal-tolerant PGPB also reduces metal bioavailability in soil and accumulation in plant tissues. These bacteria have several plant growth-promoting (PGP) characteristics such nitrogen fixation, nutrient solubilization, production of indole-3-acetic acid (IAA), siderophore, 1-aminocyclopropane-1-carboxylic acid (ACC)-deaminase, hydrolytic enzymes, abscisic acid, and biocontrol of phytopathogen even under heavy metals stress conditions [24-27]. These microbes are environment-friendly and sustainable for crop pro- 
duction [28]. Concerning the above facts, the current study was conducted to evaluate the ability of $\mathrm{Pb}$-tolerant bacterial strains to promote plant growth and antioxidant enzymatic activity and to reduce the uptake of the heavy metal in roots and leaves of spinach irrigated with treated wastewater.

\section{Material and Methods}

\subsection{Inoculum Preparation}

The four Pb-tolerant strains viz. B. megaterium (N8), B. safensis (N11), Bacillus sp. (N18), and B. megaterium (N29) were collected from the gene bank of Soil Microbiology and Biotechnology Laboratory, Department of Soil Science, the Islamia University of Bahawalpur, Pakistan [24]. The inoculum of these strains was prepared by growing in Dworkin and Foster minimal salt media composed of sucrose $(10 \mathrm{~g}), \mathrm{K}_{2} \mathrm{HPO}_{4}(2.5 \mathrm{~g}), \mathrm{KH}_{2} \mathrm{PO}_{4}(2.5 \mathrm{~g})$, $\left(\mathrm{NH}_{4}\right)_{2} \mathrm{HPO}_{4}(1.0 \mathrm{~g}), \mathrm{MgSO}_{4} .7 \mathrm{H}_{2} \mathrm{O}(0.2 \mathrm{~g}), \mathrm{FeSO}_{4} .7 \mathrm{H}_{2} \mathrm{O}(0.01 \mathrm{~g}), \mathrm{MnSO}_{4} .7 \mathrm{H}_{2} \mathrm{O}(0.007 \mathrm{~g})$, and agar powder $(15 \mathrm{~g})$ were dissolved in one liter of distilled water [29]. Bacterial inoculum of cell count $10^{8}$ colony-forming unit $\mathrm{mL}^{-1}$ was used to inoculate spinach seeds.

\subsection{Soil and Water Analysis}

The soil used for the pot trial was collected from farmland and analyzed for soil physicochemical parameters by following the standard method of Ryan et al. [30]. The organic matter contents were estimated through the ignition method [31]. The Kjeldahl method was adopted for the determination of soil nitrogen [32]. The method of Watanabe and Olsen [33] was used for the determination of available phosphorus. Extractable potassium contents were determined through a flame photometer [30]. The soil samples were digested with an $\mathrm{HNO}_{3}: \mathrm{HClO}_{4}$ mixture and subjected to atomic absorption spectrophotometer for determination of $\mathrm{Pb}$ contents in soil [30]. The resulting soil physicochemical characteristics are given in Table 1. The treated wastewater was collected from the treatment plant of the Islamia University, Bahawalpur, Pakistan. A good quality canal water which is mostly used for irrigation purposes was taken from Bahawal canal, Bahawalpur, originating from Islam Headworks on the River Sutlej in Hasilpur, Pakistan. The treated wastewater, canal water, and mixture of these waters were characterized and results are depicted in Table 2. The safe limit of chemical characteristics of irrigation water sources were reported according to water quality guidelines for irrigation [34].

Table 1. Physical and chemical characteristics of the soil used for pot trial.

\begin{tabular}{ccc}
\hline Characteristics & Units & Value/Class \\
\hline Sand & $\%$ & 44 \\
Silt & $\%$ & 42 \\
Clay & $\%$ & 14 \\
Soil texture & - & Loam \\
Saturation percentage & - & 38.0 \\
pHs & - & 1.73 \\
ECe & $\mathrm{dS} \mathrm{m}{ }^{-1}$ & 3.75 \\
Available phosphorus & $\mathrm{mg} \mathrm{kg}^{-1}$ & 149 \\
Extractable potassium & $\mathrm{mg} \mathrm{kg}^{-1}$ & 0.47 \\
Organic matter & $\%$ & 0.05 \\
Total nitrogen & $\%$ & 0.47 \\
Total Pb & $\mathrm{mg} \mathrm{kg}^{-1}$ & \\
\hline
\end{tabular}


Table 2. Characteristics of the water sources applied in a pot trial.

\begin{tabular}{ccccc}
\hline Characteristics & Sewage Water & Mixed Water & Canal Water & Safe Limit \\
\hline $\mathrm{EC}\left(\mu \mathrm{cm}^{-1}\right)$ & 2610 & 1670 & 410 & 1500 \\
$\mathrm{pH}$ & 6.30 & 7.20 & 7.5 & $6.5-8.4$ \\
$\mathrm{Ca}^{2+}+\mathrm{Mg}^{2+}\left(\mathrm{meq} \mathrm{L}^{-1}\right)$ & 13.80 & 9.30 & 3.94 & - \\
$\mathrm{CO}_{3}\left(\mathrm{meq} \mathrm{L}^{-1}\right)$ & 0.0 & 0.0 & 0.0 & - \\
$\mathrm{HCO}_{3}\left(\mathrm{meq} \mathrm{L}^{-1}\right)$ & 7.24 & 6.48 & 5.42 & $<610$ \\
$\mathrm{SAR}_{\mathrm{BOD}\left(\mathrm{mg} \mathrm{L}^{-1}\right)}^{10.08}$ & 9.95 & 5.25 & $<7.5$ \\
$\mathrm{COD}\left(\mathrm{mg} \mathrm{L}^{-1}\right)$ & 1.17 & 0.78 & 0.13 & - \\
$\mathrm{Fe}\left(\mathrm{mg} \mathrm{L}^{-1}\right)$ & 138.8 & 118.8 & 94.5 & - \\
$\mathrm{Cu}\left(\mathrm{mg} \mathrm{L}^{-1}\right)$ & 2.28 & 1.90 & 1.57 & 5.0 \\
$\mathrm{Mn}\left(\mathrm{mg} \mathrm{L}^{-1}\right)$ & 1.01 & 0.23 & 0.15 & 0.2 \\
$\mathrm{Zn}\left(\mathrm{mg} \mathrm{L}^{-1}\right)$ & 0.017 & 0.016 & 0.006 & 0.2 \\
$\mathrm{~Pb}\left(\mathrm{mg} \mathrm{L}^{-1}\right)$ & 0.231 & 0.220 & 0.049 & 2.0 \\
$\mathrm{Cr}\left(\mathrm{mg} \mathrm{L}^{-1}\right)$ & 0.33 & 0.22 & 0.07 & 0.1 \\
$\mathrm{Ni}\left(\mathrm{mg} \mathrm{L}^{-1}\right)$ & 0.009 & 0.008 & 0.002 & 1.0 \\
$\mathrm{Cd}\left(\mathrm{mg} \mathrm{L}^{-1}\right)$ & 0.31 & 0.20 & 0.09 & 1.0 \\
\hline
\end{tabular}

SAR = sodium adsorption ratio; $\mathrm{BOD}=$ biological oxygen demand; $\mathrm{COD}=$ chemical oxygen demand.

\subsection{Pot Trial}

A pot trial was performed to check the ability of Pb-tolerant Bacillus strains to promote plant growth and antioxidant activity and to reduce metal uptake in roots and leaves of spinach in treated wastewater. The broth culture, peat-based slurry, and sugar solution $(10 \%)$ were mixed and coated on spinach seeds uniformly for all the treatment groups except the control treatment. The uninoculated control seeds were also coated with peatbased slurry and sugar without bacterial culture. The ten inoculated spinach seeds were sown in each earthen pot and all the earthen pots used in the current study were of similar size filled with the same amount of soil. Pots were organized in a completely randomized design (CRD) having four replications under natural environmental conditions. Three irrigation sources including (i) treated wastewater, (ii) mixed treated wastewater + canal water, and (iii) canal water were applied uniformly for all groups of treatment including the uninoculated control group to meet water requirements. The characteristics of applied water treatment are given in Table 2. All other experimental conditions including sunlight, temperature, humidity were also kept similar for all sets of treatment groups. The antioxidant enzymatic activity of spinach leaves was evaluated after forty-days after germination. At physiology maturity, plants were harvested and analyzed for the growth attributes and heavy metal concentrations in plant roots and leaves were observed.

\subsection{Determination of Antioxidant Enzymes Activities and Crude Protein}

The top second leaves of spinach were collected and analyzed for antioxidant enzymatic activities including catalase (CAT), guaiacol peroxidase (POD), superoxide dismutase (SOD), and ascorbate peroxidases (POX) activities. The leaves samples were frozen and homogenized using a grinder. Leaves were homogenized in a mortar with $50 \mathrm{mM}$ phosphate buffer. The mixer was filtered and centrifuged. The supernatant was used to determine CAT activity by following the method of Dhindsa et al. [35]. The POD and SOD activities were determined by following Gorin et al. [36] and Beauchamp and Fridovich [37]. The crude protein in spinach leaves was determined by following the method of Thimmaiah [38].

\subsection{Heavy Metal Analysis}

Plant leaves and roots were dried at $67^{\circ} \mathrm{C}$ until constant weight. The samples were digested with concentrated $\mathrm{H}_{2} \mathrm{SO}_{4}$ by raising the temperature to $145^{\circ} \mathrm{C}$ for one hour. Further, samples were again digested with tri-acid mixtures for a further one hour. The digested samples were allowed and diluted up to $100 \mathrm{~mL}$ with double-distilled water. 
The digested samples were used to record $\mathrm{Ni}, \mathrm{Cr}, \mathrm{Cd}$, and $\mathrm{Pb}$ concentrations on Atomic Absorption Spectrophotometer [39].

\subsection{Statistical Analysis}

The data of growth and physiological attributes and metal concentration in roots and leaves of spinach were analyzed using a two-way complete randomized design (CRD) with a factorial arrangement. The means of four replications were compared using the least significant difference (LSD) test at a 5\% probability level [40].

\section{Results}

The soil used for the pot experiment illustrated the cultivation of spinach (Table 1). The $\mathrm{Pb}$-tolerant bacterial strains were evaluated for growth promotion of spinach with treated wastewater, canal water, and mixer of both. After harvesting the plant samples were collected for the determination of plant growth, antioxidant activities, and heavy metal uptake in plant roots and leaves. Our results revealed that inoculation with Pb-tolerant strains ameliorates the deleterious effects of sewage wastewater stress in spinach. Results are given below:

\subsection{Effect of Pb-Tolerant Bacillus Strains on Plant Growth Parameters under Different Water Treatments}

The application of treated wastewater promoted the plant growth of spinach; however, this increase was more dominant in spinach plants inoculated with Pb-tolerant Bacillus strains compared to the uninoculated control (Tables 3 and 4). Strain B. safensis (N11) and Bacillus sp. (N18) reported a maximum increase in shoot length with an increase of up to $19.8 \%$ and $19.3 \%$, respectively, compared to uninoculated control plants treated with treated wastewater. Strain Bacillus sp. (N18) applied in mixed water treatment also reported a better shoot length with an increase of up to $27.1 \%$ over the uninoculated control (Figure 1 and Table 3). The highest root length in treated wastewater treatment was observed due to Bacillus sp. (N18) with an increase of up to $28.2 \%$ compared to uninoculated control (Figure 2 and Table 4). This strain also reported a maximum increase of $25.3 \%$ in root length of spinach plants treated with mixed water.

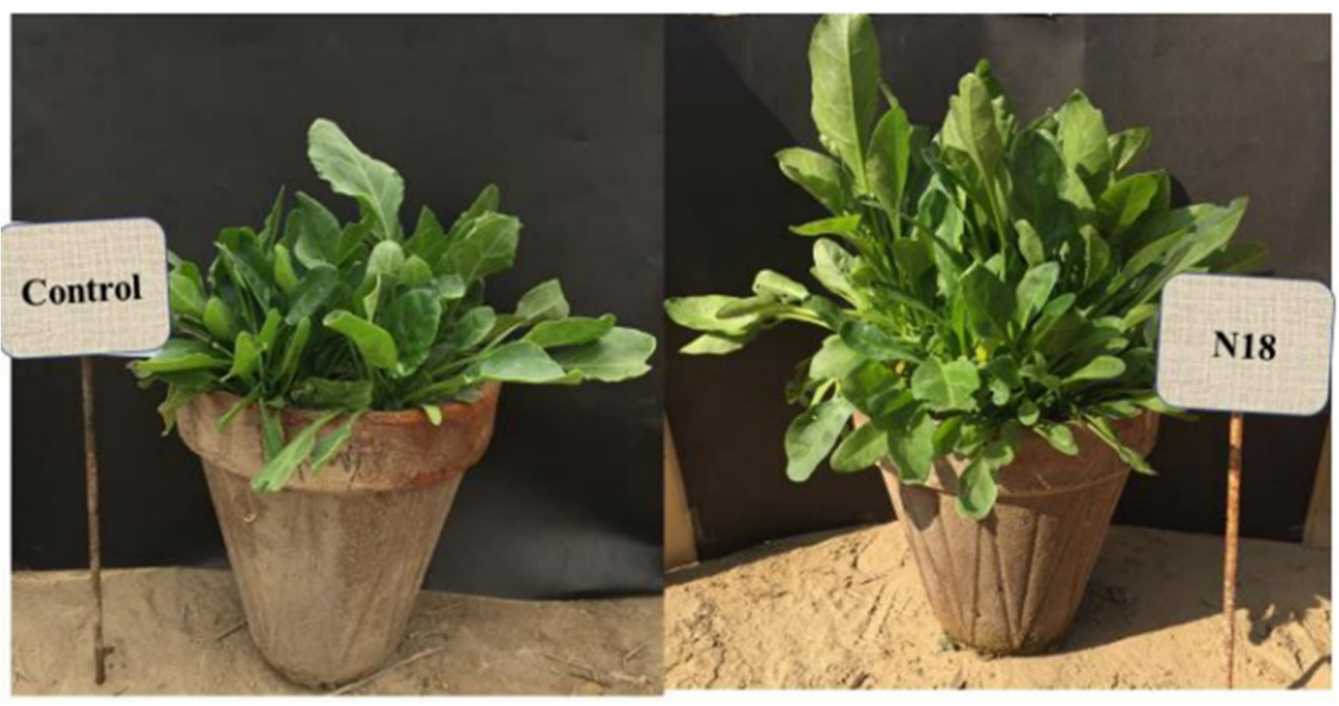

Figure 1. Effect of Pb-tolerant Bacillus strain and treated wastewater on spinach in a pot trial. 
Table 3. Effect of Pb-tolerant Bacillus strains on the root growth of spinach plants under treated wastewater, mixed water, and canal water treatment.

\begin{tabular}{|c|c|c|c|c|}
\hline Inoculation & Leaf Area $\left(\mathrm{cm}^{2}\right)$ & Shoot Length (cm) & Shoot Fresh Weight (kg) & Shoot Dry Weight (kg) \\
\hline \multicolumn{5}{|l|}{ Canal water } \\
\hline Uninoculated control & $104 \pm 1.33^{\mathrm{j}}$ & $12.2 \pm 0.15^{\mathrm{d}}$ & $1.45 \pm 0.01^{h}$ & $0.59 \pm 0.01^{h}$ \\
\hline B. megaterium (N8) & $125 \pm 0.87 \mathrm{gh}$ & $15.1 \pm 0.68^{\mathrm{d}-\mathrm{g}}$ & $1.73 \pm 0.03^{\mathrm{fg}}$ & $0.68 \pm 0.04^{\mathrm{gh}}$ \\
\hline B. safensis (N11) & $130 \pm 1.03^{\mathrm{fg}}$ & $15.5 \pm 0.29^{c-g}$ & $1.67 \pm 0.03 \mathrm{~g}$ & $0.71 \pm 0.03^{g}$ \\
\hline Bacillus sp. (N18) & $129 \pm 1.44 \mathrm{fg}$ & $14.2 \pm 0.91^{\mathrm{e}-\mathrm{g}}$ & $1.82 \pm 0.02^{\mathrm{f}}$ & $0.76 \pm 0.01 \mathrm{~g}$ \\
\hline B. megaterium (N29) & $130 \pm 1.56^{\mathrm{fg}}$ & $13.5 \pm 0.48^{\mathrm{fg}}$ & $1.75 \pm 0.03^{\mathrm{fg}}$ & $0.75 \pm 0.02 \mathrm{~g}$ \\
\hline \multicolumn{5}{|l|}{ Mixed water } \\
\hline Uninoculated control & $112 \pm 1.41^{\mathrm{i}}$ & $14.5 \pm 0.55^{\mathrm{e}-\mathrm{g}}$ & $2.62 \pm 0.02 e^{e}$ & $1.04 \pm 0.04^{\mathrm{f}}$ \\
\hline B. megaterium (N8) & $133 \pm 1.23$ ef & $17.5 \pm 1.16^{\mathrm{c}-\mathrm{e}}$ & $2.76 \pm 0.03^{\mathrm{d}}$ & $1.23 \pm 0.05 \mathrm{de}$ \\
\hline B. safensis (N11) & $148 \pm 1.72^{\mathrm{ab}}$ & $18.2 \pm 0.60^{b-d}$ & $3.23 \pm 0.02^{\mathrm{c}}$ & $1.30 \pm 0.01^{b-d}$ \\
\hline Bacillus sp. (N18) & $140 \pm 1.35^{\mathrm{cd}}$ & $17.1 \pm 0.64^{\mathrm{c}-\mathrm{e}}$ & $3.38 \pm 0.01^{\mathrm{b}}$ & $1.30 \pm 0.01^{b-d}$ \\
\hline B. megaterium (N29) & $137 \pm 1.81^{\mathrm{de}}$ & $16.6 \pm 0.68^{c-f}$ & $3.34 \pm 0.03^{b}$ & $1.27 \pm 0.01^{\mathrm{cd}}$ \\
\hline \multicolumn{5}{|l|}{ Treated wastewater } \\
\hline Uninoculated control & $118 \pm 2.01 \mathrm{hi}$ & $18.7 \pm 0.79 \mathrm{bc}$ & $2.86 \pm 0.02^{d}$ & $1.13 \pm 0.01$ ef \\
\hline B. megaterium (N8) & $133 \pm 1.31$ ef & $21.4 \pm 0.36^{\mathrm{ab}}$ & $3.18 \pm 0.01^{\mathrm{c}}$ & $1.30 \pm 0.02^{b-d}$ \\
\hline B. safensis (N11) & $154 \pm 1.55^{\mathrm{a}}$ & $22.4 \pm 1.16^{\mathrm{a}}$ & $3.56 \pm 0.02^{\mathrm{a}}$ & $1.44 \pm 0.01^{\mathrm{a}}$ \\
\hline Bacillus sp. (N18) & $153 \pm 1.24^{\mathrm{a}}$ & $22.3 \pm 0.61^{\mathrm{a}}$ & $3.62 \pm 0.01^{\mathrm{a}}$ & $1.39 \pm 0.01^{\mathrm{ab}}$ \\
\hline B. megaterium (N29) & $146 \pm 1.06^{\mathrm{bc}}$ & $21.3 \pm 0.39 \mathrm{ab}$ & $3.59 \pm 0.03^{\mathrm{a}}$ & $1.35 \pm 0.02^{a-c}$ \\
\hline \multicolumn{5}{|l|}{ Water treatments } \\
\hline Canal water & $124^{\mathrm{c}}$ & $14.11^{c}$ & $1.68^{\mathrm{c}}$ & $0.69^{c}$ \\
\hline Mixed water & $134^{\mathrm{b}}$ & $16.78^{b}$ & $3.07^{b}$ & $1.23^{\mathrm{b}}$ \\
\hline Treated wastewater & $141^{\mathrm{a}}$ & $21.18^{a}$ & $3.36^{\mathrm{a}}$ & $1.32^{\mathrm{a}}$ \\
\hline
\end{tabular}

Means sharing different letters are statistically significant from each other at a $5 \%$ level of probability.

Table 4. Effect of Pb-tolerant Bacillus strains on the root growth of spinach plants under treated wastewater, mixed water, and canal water treatment.

\begin{tabular}{|c|c|c|c|}
\hline Inoculation & Root Length (cm) & Root Fresh Weight (kg) & Root Dry Weight (kg) \\
\hline \multicolumn{4}{|l|}{ Canal water } \\
\hline Uninoculated control & $16.9 \pm 0.61^{\mathrm{e}-\mathrm{g}}$ & $0.69 \pm 0.01 \mathrm{~g}$ & $0.44 \pm 0.01^{\mathrm{j}}$ \\
\hline B. megaterium (N8) & $19.9 \pm 0.78^{a-c}$ & $0.76 \pm 0.00 \mathrm{fg}$ & $0.49 \pm 0.00^{\mathrm{i}}$ \\
\hline B. safensis (N11) & $20.5 \pm 0.85^{b-e}$ & $0.80 \pm 0.01^{\mathrm{fg}}$ & $0.53 \pm 0.01 \mathrm{hi}$ \\
\hline Bacillus sp. (N18) & $19.1 \pm 0.62^{\mathrm{fg}}$ & $0.87 \pm 0.012^{f}$ & $0.55 \pm 0.01^{h}$ \\
\hline B. megaterium (N29) & $18.8 \pm 0.54 \mathrm{fg}$ & $0.82 \pm 0.00^{\mathrm{fg}}$ & $0.50 \pm 0.00 \mathrm{hi}$ \\
\hline \multicolumn{4}{|l|}{ Mixed water } \\
\hline Uninoculated control & $19.8 \pm 0.47 \mathrm{~g}$ & $1.31 \pm 0.03^{\mathrm{e}}$ & $0.93 \pm 0.01^{\mathrm{g}}$ \\
\hline B. megaterium (N8) & $24.0 \pm 1.18^{\mathrm{e}-\mathrm{g}}$ & $1.47 \pm 0.01^{\mathrm{de}}$ & $1.10 \pm 0.00^{\mathrm{f}}$ \\
\hline B. safensis (N11) & $23.0 \pm 0.76^{\mathrm{d}-\mathrm{f}}$ & $1.61 \pm 0.01^{\mathrm{cd}}$ & $1.20 \pm 0.01^{\mathrm{e}}$ \\
\hline Bacillus sp. (N18) & $24.8 \pm 0.35^{\mathrm{ab}}$ & $1.65 \pm 0.13^{\mathrm{cd}}$ & $1.17 \pm 0.01^{\mathrm{e}}$ \\
\hline B. megaterium (N29) & $21.2 \pm 0.36^{\mathrm{c}-\mathrm{f}}$ & $1.59 \pm 0.01 \mathrm{~cd}$ & $1.16 \pm 0.01^{\mathrm{e}}$ \\
\hline \multicolumn{4}{|l|}{ Treated wastewater } \\
\hline Uninoculated control & $21.3 \pm 1.20^{c-f}$ & $1.64 \pm 0.01^{\mathrm{cd}}$ & $1.31 \pm 0.01^{\mathrm{d}}$ \\
\hline B. megaterium (N8) & $25.6 \pm 0.71^{\mathrm{ab}}$ & $1.86 \pm 0.02^{b}$ & $1.50 \pm 0.02^{\mathrm{c}}$ \\
\hline B. safensis (N11) & $25.6 \pm 0.44^{\mathrm{ab}}$ & $1.90 \pm 0.01^{b}$ & $1.61 \pm 0.01^{b}$ \\
\hline Bacillus sp. (N18) & $27.3 \pm 0.23^{\mathrm{a}}$ & $2.11 \pm 0.01^{\mathrm{a}}$ & $1.70 \pm 0.01^{\mathrm{a}}$ \\
\hline B. megaterium (N29) & $23.8 \pm 0.54^{\mathrm{a}-\mathrm{d}}$ & $1.93 \pm 0.01^{b}$ & $1.60 \pm 0.01^{b}$ \\
\hline
\end{tabular}


Table 4. Cont

\begin{tabular}{llll}
\hline Inoculation & Root Length $(\mathbf{c m})$ & Root Fresh Weight $(\mathbf{k g})$ & Root Dry Weight $(\mathbf{k g})$ \\
\hline Water treatments & & & \\
\hline Canal water & $19.01^{\mathrm{c}}$ & $0.79^{\mathrm{c}}$ & $0.50^{\mathrm{c}}$ \\
Mixed water & $22.53^{\mathrm{b}}$ & $1.53^{\mathrm{b}}$ & $1.11^{\mathrm{b}}$ \\
Treated wastewater & $24.71^{\mathrm{a}}$ & $1.91^{\mathrm{a}}$ & $1.55^{\mathrm{a}}$ \\
\hline
\end{tabular}

Means sharing different letters are statistically significant from each other at a $5 \%$ level of probability.

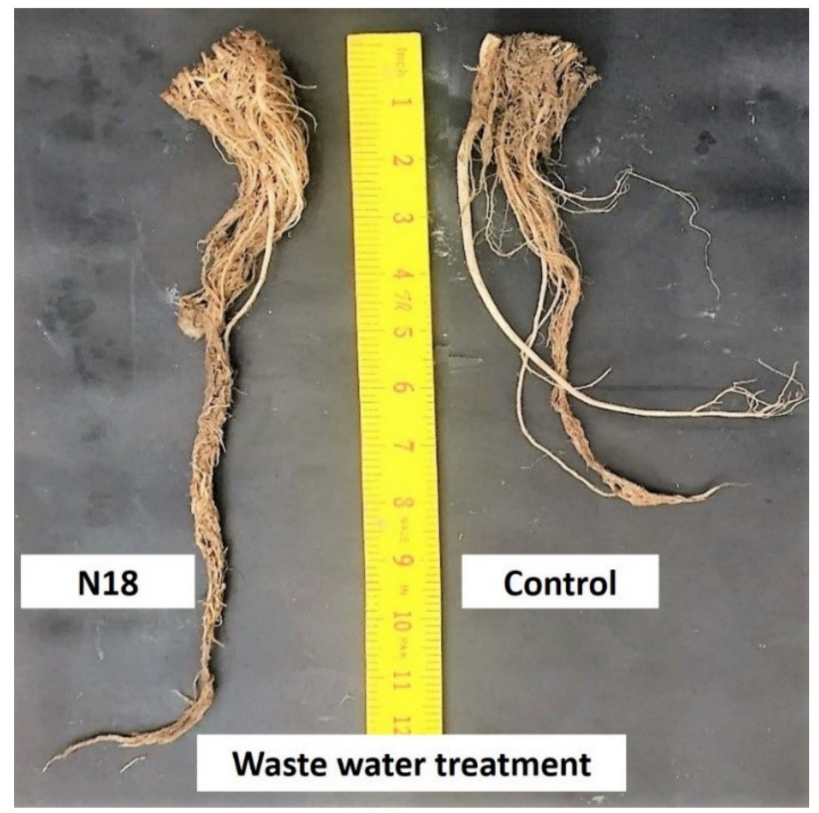

Figure 2. Effect of Pb-tolerant Bacillus strain and treated wastewater on root length of spinach in a pot trial.

The inoculation with B. safensis (N11), Bacillus sp. (N18), and B. megaterium (N29) showed a maximum increase in shoot fresh weight and shoot dry weight of spinach plant treated with treated wastewater followed by mixed water compared to uninoculated control. These strains were nonsignificant to each other in treated wastewater and mixed water treatments; however, they were significantly different from uninoculated control (Figure 1 and Table 3). In treated wastewater treatment, a maximum increase of up to $26.6 \%$ in shoot fresh weight and $27.4 \%$ in shoot dry weight was reported by spinach plants inoculated with Bacillus sp. (N18) and B. safensis (N11), respectively, compared to the uninoculated control.

The spinach plants treated with treated wastewater reported a maximum increase in root fresh and dry weight compared to mixed and canal water treatments (Figure 2 and Table 4). In treated wastewater treatment, a maximum increase of $28.7 \%$ in root fresh weight and $29.8 \%$ in root dry weight of spinach was reported by Bacillus sp. (N18) compared to the uninoculated control. Similarly, this strain also produced a maximum increase of up to $26.0 \%$ in root fresh weight and $25.8 \%$ in root dry weight of spinach over the uninoculated control plants treated with mixed water.

The Pb-tolerant Bacillus strains also improved the leaf area of spinach plants treated with treated wastewater compared to the uninoculated control (Table 3). Strains B. safensis (N11) and Bacillus sp. (N18) reported maximum leaf area having an increase of up to 30.5\% and $29.7 \%$, respectively, in treated wastewater treatment compared to the uninoculated control. These strains also reported $32.1 \%$ and $25.0 \%$, respectively, more leaf area than the uninoculated control. 


\subsection{Effect of Pb-Tolerant Bacillus Strains on Antioxidant Enzymes Activities under Different} Water Treatments

The maximum crude protein contents with an increase of $8 \%$ were observed from treated wastewater by inoculation of B. safensis (N11) and were non-significant with B. megaterium (N29) (Figure 3). The inoculation with B. safensis (N11) showed 8.4\% more crude protein contents and was nonsignificant to Bacillus sp. (N18) and B. megaterium (N29) under nixed water treatment.

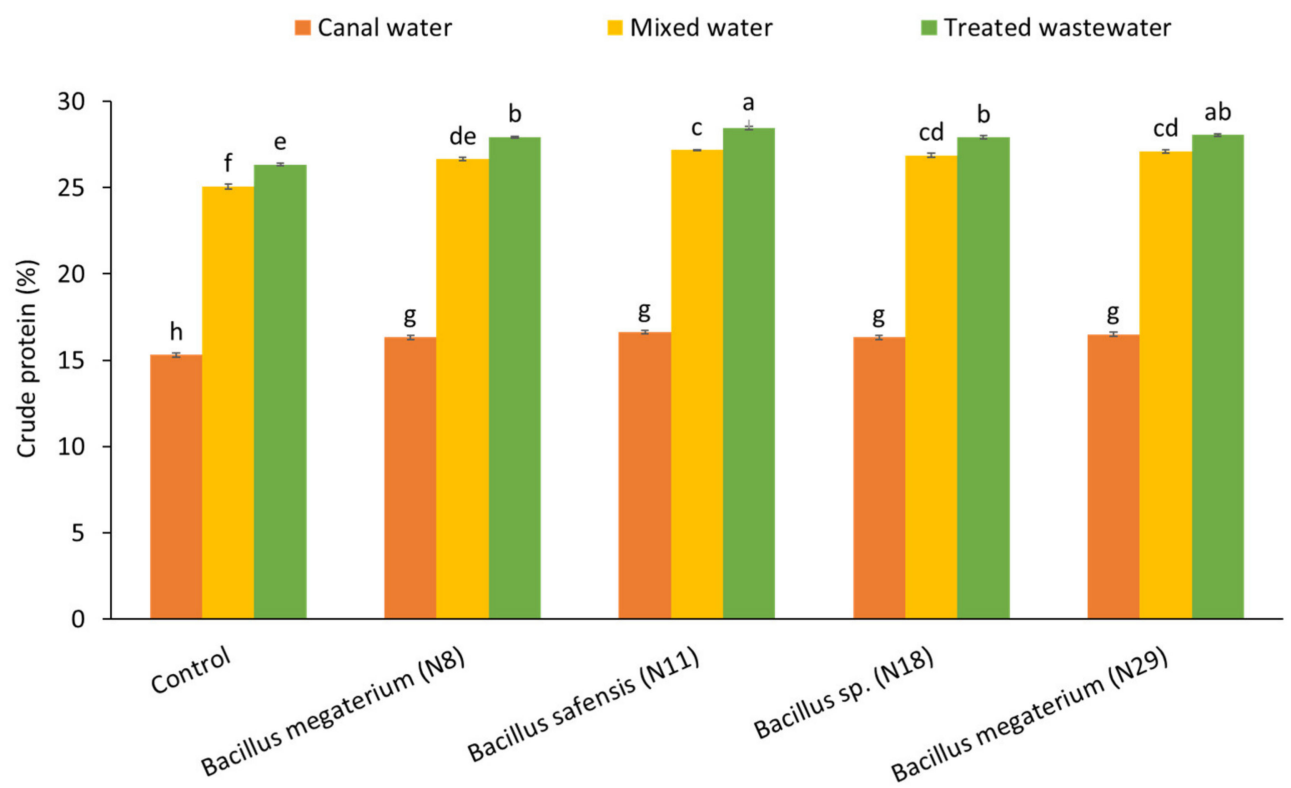

Figure 3. Effect of Pb-tolerant Bacillus strains on protein contents of spinach plants under wastewater, mixed water, canal water conditions in pot trial; $(n=4)$; Bars sharing different letters are statistically significant from each other at $5 \%$ level of probability.

The Pb-tolerant Bacillus strains showed an increase in antioxidant enzymes activities in spinach plants of all water treatments compared to the uninoculated control. Comparison of water treatments revealed that these bacterial strains showed the highest increase in antioxidant enzymatic activities of spinach plants treated with treated wastewater treatment (Figure 4). The Pb-tolerant Bacillus strains promoted catalase activity among all water treatments, however, this increase was nonsignificant compared to the uninoculated control plants treated with mixed water and canal water (Figure 4A). In treated wastewater treatment, the maximum catalase activity was reported by Bacillus sp. (N18) with an increase of up to $28.7 \%$ over the uninoculated control. The increase in POD activity ranging from $14 \%$ to $25 \%$ was observed in treated wastewater treatment over the uninoculated control. Under canal water treatment, Pb-tolerant bacterial strains promoted POD activity ranging from $8 \%$ to $23 \%$ compared to the uninoculated control (Figure $4 \mathrm{~B}$ ). These bacterial strains also promoted SOD activity ranging from $4 \%$ to $27 \%$ compared to the uninoculated control under canal water treatment. Similarly, inoculation also improved the SOD activity from $6 \%$ to $29 \%$ compared to uninoculated control in treated wastewater treatment (Figure $4 \mathrm{C}$ ). The maximum increase in POX activity was reported by B. safensis (N11) followed by Bacillus sp. (N18) in treated wastewater and canal water (Figure 4D). B. safensis (N11) reported the highest POX enzymatic activities over the uninoculated control. 

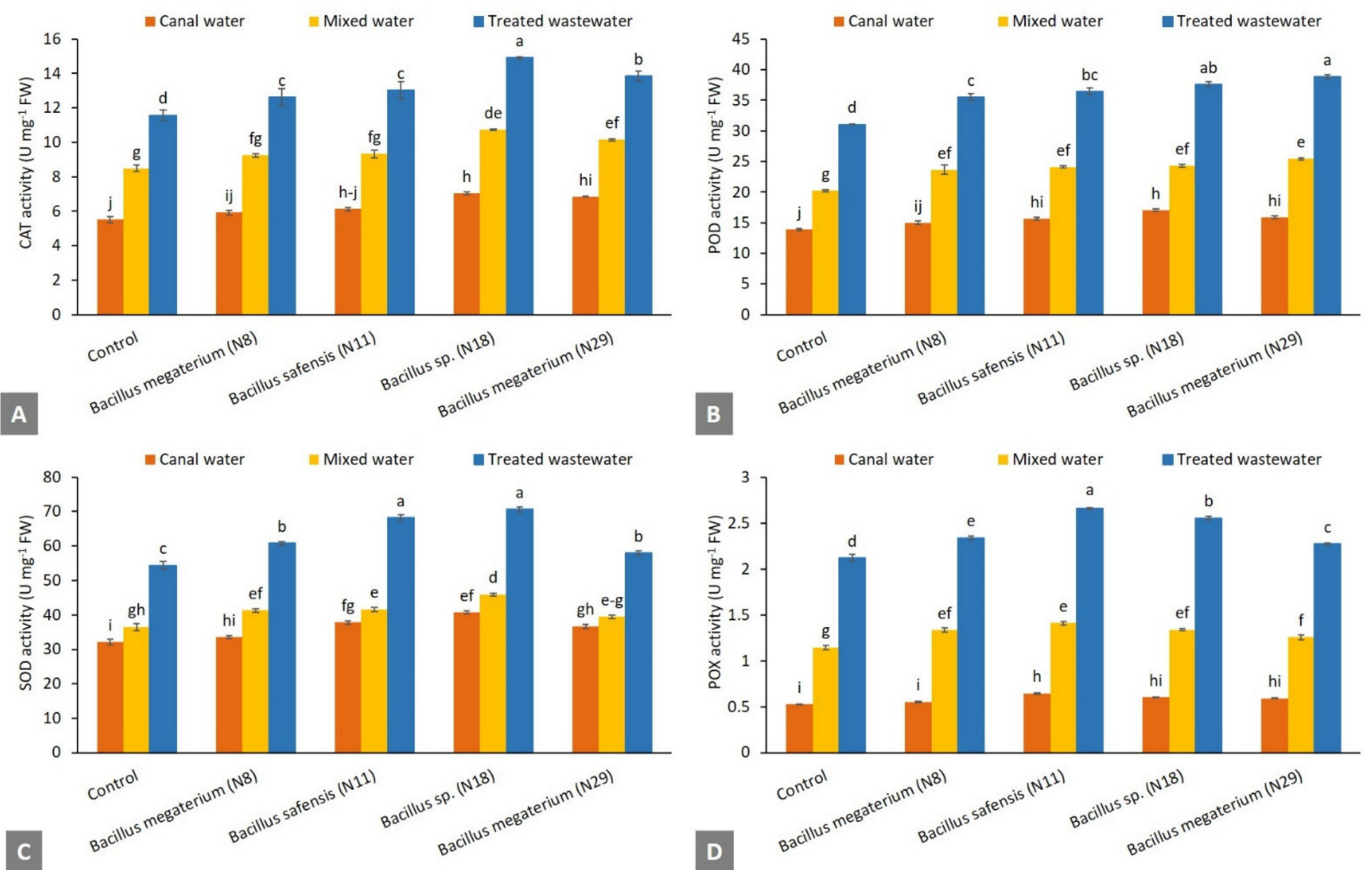

Figure 4. Effect of Pb-tolerant Bacillus strains on antioxidant enzymes: Catalase activity (A); Guaiacol peroxidase activity (B); Superoxide dismutase activity (C); and Peroxidase activity (D) of spinach plants under wastewater, mixed water, canal water conditions in pot trial; $(n=4)$; Bars sharing different letters are statistically significant from each other at $5 \%$ level of probability $; \mathrm{CAT}=$ Catalase POD $=$ Guaiacol peroxidase SOD = Superoxide dismutase POX = Peroxidase.

\subsection{Effect of Pb-Tolerant Bacillus Strains on Heavy Metal Uptake under Different} Water Treatments

\subsubsection{Nickel Contents in Spinach}

The maximum reduction in leaves Ni contents was reported by B. safensis (N11) with a reduction of $7.8 \%$ over the uninoculated control under treated wastewater treatment (Table 5). The highest reduction in leave Ni contents was observed from B. megaterium (N8) which was nonsignificant to the uninoculated control under canal water treatment. The inoculation with Bacillus sp. (N18) followed by B. safensis (N11) reported a maximum reduction in root $\mathrm{Ni}$ contents compared to the uninoculated control under treated wastewater treatment (Table 6). The maximum reduction of roots $\mathrm{Ni}$ contents was reported by Bacillus sp. (N18) over the uninoculated control under mixed water treatment. B. megaterium (N29) was least effective to cause a reduction of up to $1.8 \%$ in root Ni contents compared to the uninoculated control under mixed water treatment.

\subsubsection{Chromium Contents in Spinach}

Chromium contents of spinach leaves were significantly reduced with the application of Pb-tolerant Bacillus strains in contrast to the uninoculated control except for canal water where nonsignificant response by all strains was reported (Table 5). A maximum reduction in leaves $\mathrm{Cr}$ contents was reported by $B$. safensis (N11) that was nonsignificant with $B$. megaterium (N8) and Bacillus sp. (N18) under treated wastewater treatment. The maximum decrease of up to $13 \%$ in roots $\mathrm{Cr}$ contents were reported by Bacillus sp. (N18) compared to the uninoculated control under treated wastewater (Table 6). B. safensis (N11) reported the 
maximum reduction of up to $8.3 \%$ in roots $\mathrm{Cr}$ contents over uninoculated control under mixed water treatment.

Table 5. Effect of Pb-tolerant Bacillus strains on heavy metal contents of spinach leaves under sewage wastewater, mixed water, and canal water treatments.

\begin{tabular}{|c|c|c|c|c|}
\hline Inoculation & $\mathrm{Ni}\left(\mathrm{mg} \mathrm{kg} \mathrm{k}^{-1}\right)$ & $\mathrm{Cr}\left(\mathrm{mg} \mathrm{kg}{ }^{-1}\right)$ & $\mathrm{Cd}\left(\mathrm{mg} \mathrm{kg}{ }^{-1}\right)$ & $\mathrm{Pb}\left(\mathrm{mg} \mathrm{kg}^{-1}\right)$ \\
\hline \multicolumn{5}{|l|}{ Canal water } \\
\hline Uninoculated control & $0.37 \pm 0.001^{\mathrm{h}}$ & $0.19 \pm 0.009 \mathrm{~g}$ & $0.017 \pm 0.003^{\mathrm{d}}$ & $0.78 \pm 0.006^{\mathrm{h}}$ \\
\hline B. megaterium (N8) & $0.34 \pm 0.001^{h}$ & $0.18 \pm 0.007^{g}$ & $0.017 \pm 0.000^{\mathrm{d}}$ & $0.71 \pm 0.006^{h}$ \\
\hline B. safensis (N11) & $0.35 \pm 0.001^{h}$ & $0.17 \pm 0.006^{g}$ & $0.017 \pm 0.000^{\mathrm{d}}$ & $0.73 \pm 0.005^{h}$ \\
\hline Bacillus sp. (N18) & $0.35 \pm 0.001^{h}$ & $0.18 \pm 0.004^{g}$ & $0.017 \pm 0.000^{\mathrm{d}}$ & $0.71 \pm 0.002^{h}$ \\
\hline B. megaterium (N29) & $0.36 \pm 0.000^{h}$ & $0.18 \pm 0.008^{g}$ & $0.017 \pm 0.000^{d}$ & $0.78 \pm 0.004^{h}$ \\
\hline \multicolumn{5}{|l|}{ Mixed water } \\
\hline Uninoculated control & $3.00 \pm 0.001^{\mathrm{e}}$ & $0.74 \pm 0.030^{\mathrm{cd}}$ & $0.38 \pm 0.011^{\mathrm{ab}}$ & $1.86 \pm 0.002^{\mathrm{cd}}$ \\
\hline B. megaterium (N8) & $2.75 \pm 0.001^{g}$ & $0.72 \pm 0.006^{\mathrm{c}-\mathrm{e}}$ & $0.35 \pm 0.008^{b c}$ & $1.81 \pm 0.003 \mathrm{de}$ \\
\hline B. safensis (N11) & $2.82 \pm 0.001 \mathrm{fg}$ & $0.68 \pm 0.010^{\text {ef }}$ & $0.33 \pm 0.007^{c}$ & $1.68 \pm 0.006^{\mathrm{fg}}$ \\
\hline Bacillus sp. (N18) & $2.76 \pm 0.001 \mathrm{~g}$ & $0.67 \pm 0.009^{\mathrm{f}}$ & $0.36 \pm 0.009 b c$ & $1.65 \pm 0.004^{g}$ \\
\hline B. megaterium (N29) & $2.90 \pm 0.001^{\mathrm{f}}$ & $0.70 \pm 0.005^{\mathrm{d}-\mathrm{f}}$ & $0.36 \pm 0.006^{b c}$ & $1.75 \pm 0.001^{\text {ef }}$ \\
\hline \multicolumn{5}{|l|}{ Treated wastewater } \\
\hline Uninoculated control & $4.97 \pm 0.001^{\mathrm{a}}$ & $0.85 \pm 0.009^{\mathrm{a}}$ & $0.40 \pm 0.012^{\mathrm{a}}$ & $2.02 \pm 0.006^{\mathrm{a}}$ \\
\hline B. megaterium (N8) & $4.67 \pm 0.001^{c}$ & $0.81 \pm 0.006^{\mathrm{ab}}$ & $0.37 \pm 0.006^{\mathrm{ab}}$ & $1.89 \pm 0.008^{b c}$ \\
\hline B. safensis (N11) & $4.58 \pm 0.001^{\mathrm{d}}$ & $0.77 \pm 0.010^{b c}$ & $0.36 \pm 0.006^{b c}$ & $1.78 \pm 0.005^{\mathrm{e}}$ \\
\hline Bacillus sp. (N18) & $4.69 \pm 0.001^{c}$ & $0.80 \pm 0.005^{\mathrm{ab}}$ & $0.37 \pm 0.008^{a b}$ & $1.86 \pm 0.004^{\mathrm{cd}}$ \\
\hline B. megaterium (N29) & $4.83 \pm 0.000^{b}$ & $0.84 \pm 0.004^{\mathrm{a}}$ & $0.38 \pm 0.003^{\mathrm{ab}}$ & $1.95 \pm 0.002^{a b}$ \\
\hline \multicolumn{5}{|l|}{ Water treatments } \\
\hline Canal water & $0.35^{c}$ & $0.18^{c}$ & $0.02^{c}$ & $0.74^{\mathrm{c}}$ \\
\hline Mixed water & $2.85^{b}$ & $0.70^{\mathrm{b}}$ & $0.36^{\mathrm{b}}$ & $1.75^{\mathrm{b}}$ \\
\hline Treated wastewater & $4.75^{\mathrm{a}}$ & $0.81^{\mathrm{a}}$ & $0.37^{\mathrm{a}}$ & $1.90^{\mathrm{a}}$ \\
\hline
\end{tabular}

Means sharing different letters are statistically significant from each other at a $5 \%$ level of probability.

Table 6. Effect of Pb-tolerant Bacillus strains on heavy metal contents of spinach root under wastewater conditions in pot trial $(n=4)$.

\begin{tabular}{|c|c|c|c|c|}
\hline Inoculation & $\mathrm{Ni}\left(\mathrm{mg} \mathrm{kg}^{-1}\right)$ & $\mathrm{Cr}\left(\mathrm{mg} \mathrm{kg}^{-1}\right)$ & $\mathrm{Cd}\left(\mathrm{mg} \mathrm{kg}^{-1}\right)$ & $\mathrm{Pb}\left(\mathrm{mg} \mathrm{kg}^{-1}\right)$ \\
\hline \multicolumn{5}{|l|}{ Canal water } \\
\hline Uninoculated control & $0.57 \pm 0.001 \mathrm{j}$ & $0.40 \pm 0.019^{\mathrm{f}}$ & $0.07 \pm 0.004^{g}$ & $0.87 \pm 0.007^{g}$ \\
\hline B. megaterium (N8) & $0.53 \pm 0.001 \mathrm{j}$ & $0.40 \pm 0.015^{\mathrm{f}}$ & $0.06 \pm 0.001^{g}$ & $0.85 \pm 0.004 \mathrm{gh}$ \\
\hline B. safensis (N11) & $0.52 \pm 0.001^{\mathrm{j}}$ & $0.39 \pm 0.015^{f}$ & $0.06 \pm 0.001 \mathrm{~g}$ & $0.83 \pm 0.006$ gh \\
\hline Bacillus sp. (N18) & $0.55 \pm 0.000^{j}$ & $0.37 \pm 0.018^{f}$ & $0.06 \pm 0.000 \mathrm{~g}$ & $0.76 \pm 0.005^{h}$ \\
\hline B. megaterium (N29) & $0.53 \pm 0.000^{j}$ & $0.40 \pm 0.008^{f}$ & $0.07 \pm 0.001^{\mathrm{g}}$ & $0.81 \pm 0.003 \mathrm{gh}$ \\
\hline \multicolumn{5}{|l|}{ Mixed water } \\
\hline Uninoculated control & $3.93 \pm 0.001^{\mathrm{e}}$ & $0.98 \pm 0.019^{\mathrm{cd}}$ & $0.60 \pm 0.018$ de & $3.99 \pm 0.006^{b}$ \\
\hline B. megaterium (N8) & $3.77 \pm 0.000 \mathrm{~g}$ & $0.95 \pm 0.009^{\mathrm{c}-\mathrm{e}}$ & $0.58 \pm 0.006^{\text {ef }}$ & $3.72 \pm 0.002$ ef \\
\hline B. safensis (N11) & $3.69 \pm 0.001^{h}$ & $0.90 \pm 0.014^{\mathrm{e}}$ & $0.54 \pm 0.011^{\mathrm{f}}$ & $3.65 \pm 0.006^{\mathrm{f}}$ \\
\hline Bacillus sp. (N18) & $3.62 \pm 0.001^{\mathrm{i}}$ & $0.93 \pm 0.014^{\mathrm{de}}$ & $0.55 \pm 0.009^{\mathrm{f}}$ & $3.64 \pm 0.003^{f}$ \\
\hline B. megaterium (N29) & $3.86 \pm 0.001^{\mathrm{f}}$ & $0.96 \pm 0.006^{\mathrm{c}-\mathrm{e}}$ & $0.59 \pm 0.004^{\mathrm{e}}$ & $3.78 \pm 0.004^{\mathrm{de}}$ \\
\hline \multicolumn{5}{|l|}{ Treated wastewater } \\
\hline Uninoculated control & $4.94 \pm 0.000^{\mathrm{a}}$ & $1.12 \pm 0.010^{\mathrm{a}}$ & $0.72 \pm 0.011^{\mathrm{a}}$ & $4.22 \pm 0.006^{\mathrm{a}}$ \\
\hline B. megaterium (N8) & $4.68 \pm 0.001^{\mathrm{c}}$ & $1.13 \pm 0.016^{\mathrm{a}}$ & $0.69 \pm 0.015^{a b}$ & $3.83 \pm 0.006^{\mathrm{cd}}$ \\
\hline B. safensis (N11) & $4.59 \pm 0.001^{\mathrm{d}}$ & $1.01 \pm 0.018^{b c}$ & $0.64 \pm 0.010^{\mathrm{cd}}$ & $3.73 \pm 0.005^{\mathrm{d}-\mathrm{f}}$ \\
\hline Bacillus sp. (N18) & $4.54 \pm 0.001^{\mathrm{d}}$ & $0.97 \pm 0.009 \mathrm{~cd}$ & $0.67 \pm 0.006^{b c}$ & $3.66 \pm 0.006^{f}$ \\
\hline B. megaterium (N29) & $4.76 \pm 0.001^{b}$ & $1.06 \pm 0.012^{\mathrm{ab}}$ & $0.70 \pm 0.007^{a b}$ & $3.90 \pm 0.010 \mathrm{bc}$ \\
\hline
\end{tabular}


Table 6. Cont.

\begin{tabular}{|c|c|c|c|c|}
\hline Inoculation & $\mathrm{Ni}\left(\mathrm{mg} \mathrm{kg}^{-1}\right)$ & $\mathrm{Cr}\left(\mathrm{mg} \mathrm{kg}^{-1}\right)$ & $\mathrm{Cd}\left(\mathrm{mg} \mathrm{kg}^{-1}\right)$ & $\mathrm{Pb}\left(\mathrm{mg} \mathrm{kg}^{-1}\right)$ \\
\hline \multicolumn{5}{|l|}{ Water treatments } \\
\hline Canal water & $0.54^{\mathrm{c}}$ & $0.39^{c}$ & $0.06^{\mathrm{c}}$ & $0.83^{c}$ \\
\hline Mixed water & $3.77^{b}$ & $0.94^{b}$ & $0.57^{b}$ & $3.76^{b}$ \\
\hline Treated wastewater & $4.71^{\mathrm{a}}$ & $1.06^{\mathrm{a}}$ & $0.68^{a}$ & $3.87^{\mathrm{a}}$ \\
\hline
\end{tabular}

Means sharing different letters are statistically significant from each other at a $5 \%$ level of probability.

\subsubsection{Cadmium Contents in Spinach}

Inoculation with $\mathrm{Pb}$-tolerant Bacillus strains significantly reduces leaves $\mathrm{Cd}$ contents under different water treatments (Table 5). The maximum reduction in leaves Cd contents was observed in treated wastewater treatment compared to mixed water and canal water. The highest reduction in leaves Cd contents was observed from B. safensis (N11) in treated wastewater treatment. Strain B. safensis (N11) also reduces leaves Cd contents under mixed water conditions. Inoculation with B. safensis (N11) showed a maximum reduction of up to $11.4 \%$ in roots $\mathrm{Cd}$ contents treated with treated wastewater compared to the uninoculated control (Table 6). Under mixed water treatment, B. safensis (N11) and Bacillus sp. (N18) proved the most efficient strains by showing a maximum decrease of $\mathrm{Cr}$ contents up to $9.2 \%$ and $8.7 \%$, respectively, in spinach roots compared to the uninoculated control.

\subsubsection{Lead Contents in Spinach}

The maximum reduction of up to $9.7 \%$ in leave $\mathrm{Pb}$ contents was reported by $\mathrm{B}$. safensis (N11) in comparison to the uninoculated control in treated wastewater treatment (Table 5). The reduction in leaves $\mathrm{Pb}$ contents by bacterial strains was ranged from $1.4 \%$ to $9.7 \%$ compared to the uninoculated control under mixed water treatment. The tested strains were nonsignificant in contrast with the uninoculated control under canal water treatments. The highest reduction of up to $8.6 \%$ in roots $\mathrm{Pb}$ contents was reported by $B$. safensis (N11) that was nonsignificant with Bacillus sp. (N18), but significantly different from the uninoculated control in treated wastewater treatment (Table 6). Strains B. safensis (N18) and Bacillus sp. (N11) cause a reduction of up to $11 \%$ and $8.5 \%$, respectively, in roots Pb contents compared to the uninoculated control under mixed water treatments. The maximum reduction in roots $\mathrm{Pb}$ contents was given by Bacillus sp. (N18), however other strains were statistically similar with each other and the uninoculated control under canal water treatment.

\section{Discussion}

Heavy metals accumulate in food crops by continuous irrigation with sewage water [41]. Several researchers reported the considerable concentration of different trace metals in soil and then in vegetables $[42,43]$. The present study was conducted to evaluate the effect of Pb-tolerant Bacillus sp. on plant growth and heavy metals uptake in roots and leaves of spinach with treated wastewater. Results revealed that the application of sewage water causes an increase in plant growth of spinach compared to canal water and/or a mixer of canal and sewage water. However, the application of Pb-tolerant Bacillus strains causes a higher increase in growth attributes of spinach compared to the uninoculated control (Tables 3 and 4). Such beneficial effects of bacteria may be due to their effects on heavy metals mobility and availability to plants through producing chelating agents, production of organic acids, solubilization of nutrients, and changes in redox reactions [44]. Our findings are correlated with the work of Saleem et al. [19], who reported the alleviation of the poisonous effects of lead through inoculation with Pb-tolerant rhizobacteria that improves the productivity of sunflower in $\mathrm{Pb}$-contaminated conditions.

The increase in plant growth by Pb-tolerant Bacillus spp. under heavy metals toxic environments might be due to their ability to solubilize phosphorus, potassium, and zinc [45], production of phytohormones [46], siderophore [47], aminocyclopropane 1-carboxylate deaminase enzymes [48], and induces system resistance against heavy metals toxicity [49]. 
Previously, we found the tested $\mathrm{Pb}$-tolerant bacterial strains positive for these plant growthpromoting characteristics [24]. Such Pb-tolerant bacterial strains adopt advanced distinctive mechanisms to effectively thrive in the $\mathrm{Pb}$-contaminated environment deprived of imposing any adverse effects on their growth and development. They ameliorate the $\mathrm{Pb}$-toxicity through biosorption, efflux, production of metal chelators including metallothionein, exopolysaccharides, siderophores, and intracellular bioaccumulation extracellular sequestration [50]. Such heavy metal tolerant bacteria may also promote nutrient availability and uptake by recycling the organic waste in sewage water [51]. They can augment the remediation ability in plants and reduce the toxicity of contaminated soil with sewage water [52]. Heavy metals stress initiated the formation of reactive oxygen species in plants which can be overcome through promoting antioxidative enzymatic activities including CAT, POD, SOD, ascorbate peroxidase, and glutathione reductase [53]. In the present study, $\mathrm{Pb}$-tolerant Bacillus strains improved the antioxidant enzymes in terms of CAT, POD, SOD, and POX activities in spinach plants treated with sewage water compared to plants grown with the uninoculated control (Figure 4). The increase in antioxidant enzymatic activity confers direct protection against metal-stress damage caused by oxidative stress and tissue damage [54]. Metals have a high affinity for thiol groups containing enzymes and proteins, which are liable for normal cellular defense mechanisms. Above a certain point of tolerance, the physiological state of the cells of the plant will be irreversibly changed. This change is reflected by an increase in the activity of certain enzymes defined as enzyme induction in the plants as a result of the tolerance mechanism [55]. Similarly, Janmohammadi et al. [56] and Saleem et al. [19] also reported an increase in antioxidant enzymatic activities in plants treated with $\mathrm{Pb}$-contamination. They also reported that inoculation with $\mathrm{Pb}$-tolerant bacteria may cause a stimulatory effect in plant defensive mechanism that reduces malondialdehyde contents in plant and alleviate the heavy metal stress [56].

The current study showed that inoculation with Pb-tolerant Bacillus strains reduces the heavy metals $(\mathrm{Ni}, \mathrm{Cr}, \mathrm{Cd}$, and $\mathrm{Pb})$ concentration in roots and leaves of spinach compared to the uninoculated control treated with sewage water (Tables 5 and 6). The reduction in $\mathrm{Ni}, \mathrm{Cr}, \mathrm{Cd}$, and $\mathrm{Pb}$ uptake in roots and leaves of spinach treated with Pb-tolerant Bacillus strains might be due to their effectiveness in metals immobilization and reduction of their translocation in plants through precipitation, adsorption, and complex formation. These findings are in parallel to the work of Mesa-Marín et al. [57] and Khanna et al. [58]. Khanna et al. [58] reported that inoculation with Pseudomonas aeruginosa and Burkholderia gladioli mitigated Cd-stress through promoting plant growth, photosynthetic pigments, metal uptake along with protein and nonprotein bound thiols in Lycopersicon esculentum seedling. Mesa-Marín et al. [57] evaluated the effect of heavy metal resistant Bacillus strains inoculation on Spartina maritima root respiration and oxidative stress. They reported that inoculated plants showed heavy metal stress alleviation and reduction in respiratory carbon consumption promoted metal rhizo-accumulation in S. maritima plants treated with heavy metal tolerant Bacillus strains.

The tested Pb-tolerant bacterial strains in the current study showed variation in response of sewage water and canal water. These strains reduce the stress of heavy metals in sewage water by immobilizing the metals and reducing their uptake in roots and leaves of spinach (Tables 5 and 6). Among tested strains, B. safensis (N11) and Bacillus sp. (N18) were more effective in the promotion of plant growth and antioxidant enzymes activities in spinach plants with treated wastewater. Both of these strains were also found effective in the bioremediation of sewage water through immobilizing the heavy metals and reducing their uptake in plants tissues. Most of the metals accumulated in spinach leaves remained within safe limits as proposed by FAO/WHO [59] which is also suitable to be consumed as a vegetable. Previously, heavy metal stress promoted the expression in the metal transporter genes however this expression of metal transporter genes was reduced in Pb-tolerant bacteria treated seedlings [58] which might be true in the current study. 


\section{Conclusions}

The current study concluded that the application of treated wastewater promoted spinach growth and physiological attributes. The treated wastewater also causes a higher accumulation of metal in roots and leaves of spinach, however, these metals accumulation found in safe limit. The lead-tolerant strains Bacillus sp. N18 and Bacillus safensis N11 were found to be effective in the promotion of plant growth and antioxidant activities in spinach treated with sewage water. These strains were also efficient in reducing the uptake of heavy metals in roots and leaves of spinach treated with sewage water. These Pb-tolerant strains could be explored for sustainable crop production under sewage water stress conditions. These strains should be further evaluated under sewage water contaminated field conditions and biofertilizer should be formulated for the bioremediation of sewagecontaminated soil after extensive evaluation.

Author Contributions: Conceptualization, supervision, methodology, formal analysis, writing original draft preparation, writing - review and editing, N.-u.-S., M.A. and I.A.; data curation, project administration, investigation, F.N., M.Z.M., M.L.; conceptualization, funding acquisition, writingreview and editing, writing-original draft preparation, M.S.A.-M., F.S.A., A.Z.D., M.A.M. and A.A.E.-S. All authors have read and agreed to the published version of the manuscript.

Funding: This research was financially supported by the Vice Deanship of Research Chairs at King Saud University.

Institutional Review Board Statement: Not applicable.

Informed Consent Statement: Not applicable.

Data Availability Statement: The data presented in this study are available on request from the corresponding author.

Acknowledgments: This work was financially supported by the Vice Deanship of Research Chairs at King Saud University.

Conflicts of Interest: The authors declare no conflict of interest.

\section{References}

1. Valipour, M.; Singh, V.P. Global experiences on wastewater irrigation: Challenges and prospects. In Balanced Urban Development: Options and Strategies for Liveable Cities; Springer International Publishing: Cham, Switzerland, 2016; pp. $289-327$.

2. Bixio, D.; Thoeye, C.; De Koning, J.; Joksimovic, D.; Savic, D.; Wintgens, T.; Melin, T. Wastewater reuse in Europe. Desalination 2006, 187, 89-101. [CrossRef]

3. Friedel, J.K.; Langer, T.; Siebe, C.; Stahr, K. Effects of long-term waste water irrigation on soil organic matter, soil microbial biomass and its activities in central Mexico. Biol. Fertil. Soils 2000, 31, 414-421. [CrossRef]

4. Khan, N.; Bano, A. Modulation of phytoremediation and plant growth by the treatment with PGPR, Ag nanoparticle and untreated municipal wastewater. Int. J. Phytoremediation 2016, 18, 1258-1269. [CrossRef]

5. Rong, W.; Shiyu, L.; Linhao, C.; Jiangkai, L. The effect of sewage sludge application on the growth and absorption rates of $\mathrm{Pb}$ and As in water spinach. Open Life Sci. 2016, 11, 506-512. [CrossRef]

6. Tytła, M. Assessment of Heavy Metal Pollution and Potential Ecological Risk in Sewage Sludge from Municipal Wastewater Treatment Plant Located in the Most Industrialized Region in Poland-Case Study. Int. J. Environ. Res. Public Heal. 2019, 16, 2430. [CrossRef] [PubMed]

7. Rehman, K.; Fatima, F.; Waheed, I.; Akash, M.S. Prevalence of exposure of heavy metals and their impact on health conse-quences. J. Cell. Biochem. 2018, 119, 157-184. [CrossRef] [PubMed]

8. Sigel, R.K.O.; Pyle, A.M. Alternative Roles for Metal Ions in Enzyme Catalysis and the Implications for Ribozyme Chemistry. ChemInform 2007, 38. [CrossRef]

9. Jan, A.T.; Azam, M.; Siddiqui, K.; Ali, A.; Choi, I.; Haq, Q.M. Heavy metals and human health: Mechanistic insight into tox-icity and counter defense system of antioxidants. Int. J. Mol. Sci. 2015, 16, 29592-29630. [CrossRef] [PubMed]

10. Brooks, P.R.; Crowe, T.P. Combined Effects of Multiple Stressors: New Insights Into the Influence of Timing and Sequence. Front. Ecol. Evol. 2019, 7. [CrossRef]

11. Balali-Mood, M.; Naseri, K.; Tahergorabi, Z.; Khazdair, M.R.; Sadeghi, M. Toxic Mechanisms of Five Heavy Metals: Mercury, Lead, Chromium, Cadmium, and Arsenic. Front. Pharmacol. 2021, 12. [CrossRef]

12. Barrios, M.E.; Fernández, M.D.B.; Cammarata, R.V.; Torres, C.; Mbayed, V.A. Viral tools for detection of fecal contamination and microbial source tracking in wastewater from food industries and domestic sewage. J. Virol. Methods 2018, 262, 79-88. [CrossRef] 
13. Paździor, K.; Bilińska, L.; Ledakowicz, S. A review of the existing and emerging technologies in the combination of AOPs and biological processes in industrial textile wastewater treatment. Chem. Eng. J. 2018, 376, 120597. [CrossRef]

14. ATSDR. Agency for Toxic Substances and Disease Registry. 2003. Available online: http://www.atsdr.cdc.gov/ (accessed on 8 August 2021).

15. Jayasri, M.A.; Suthindhiran, K. Effect of zinc and lead on the physiological and biochemical properties of aquatic plant Lemna minor: Its potential role in phytoremediation. Appl. Water Sci. 2016, 7, 1247-1253. [CrossRef]

16. Fatemi, H.; Pour, B.E.; Rizwan, M. Isolation and characterization of lead (Pb) resistant microbes and their combined use with silicon nanoparticles improved the growth, photosynthesis and antioxidant capacity of coriander (Coriandrum sativum L.) under Pb stress. Environ. Pollut. 2020, 266. [CrossRef] [PubMed]

17. Alam, M.; Khan, M.; Khan, A.; Zeb, S.; Khan, M.A.; Amin, N.U.; Sajid, M.; Khattak, A.M. Concentrations, dietary exposure, and human health risk assessment of heavy metals in market vegetables of Peshawar, Pakistan. Environ. Monit. Assess. 2018, 190, 505. [CrossRef]

18. Abdullahi, S.; Haris, H.; Zarkasi, K.Z.; Amir, H.G. Beneficial bacteria associated with Mimosa pudica and potential to sustain plant growth-promoting traits under heavy metals stress. Bioremediation J. 2020, 25, 1-21. [CrossRef]

19. Saleem, M.; Asghar, H.N.; Zahir, Z.A.; Shahid, M. Impact of lead tolerant plant growth promoting rhizobacteria on growth, physiology, antioxidant activities, yield and lead content in sunflower in lead contaminated soil. Chemosphere 2018, 195, 606-614. [CrossRef] [PubMed]

20. Rodríguez-Sánchez, V.; Guzmán-Moreno, J.; Rodríguez-González, V.; la Torre, J.A.F.-D.; Ramírez-Santoyo, R.M.; VidalesRodríguez, L.E. Biosorption of lead phosphates by lead-tolerant bacteria as a mechanism for lead immobilization. World J. Microbiol. Biotechnol. 2017, 33, 1-11. [CrossRef] [PubMed]

21. Tiquia-Arashiro, S.M. Lead absorption mechanisms in bacteria as strategies for lead bioremediation. Appl. Microbiol. Biotechnol. 2018, 102, 5437-5444. [CrossRef]

22. Beni, A.A.; Esmaeili, A. Biosorption, an efficient method for removing heavy metals from industrial effluents: A Review. Environ. Technol. Innov. 2019, 17, 100503. [CrossRef]

23. Zeng, W.; Zhang, S.; Xia, M.; Wu, X.; Qiu, G.; Shen, L. Insights into the production of extracellular polymeric substances of Cupriavidus pauculus 1490 under the stimulation of heavy metal ions. RSC Adv. 2020, 10, 20385-20394. [CrossRef]

24. Seher, N.; Ahmad, M.; Hussain, A.; Jamil, M. Potential of exopolysaccharides producing-lead tolerant Bacillus strains for im-proving spinach growth under lead stress. Int. J. Agric. Biol. 2020, 24, 1845-1854.

25. Nazli, F.; Mustafa, A.; Ahmad, M.; Hussain, A.; Jamil, M.; Wang, X.; Shakeel, Q.; Imtiaz, M.; El-Esawi, M. A Review on Practical Application and Potentials of Phytohormone-Producing Plant Growth-Promoting Rhizobacteria for Inducing Heavy Metal Tolerance in Crops. Sustainability 2020, 12, 9056. [CrossRef]

26. Nazli, F.; Jamil, M.; Hussain, A.; Hussain, T. Exopolysaccharides and indole-3-acetic acid producing Bacillus safensis strain FN13 potential candidate for phytostabilization of heavy metals. Environ. Monit. Assess. 2020, 192, 1-16. [CrossRef] [PubMed]

27. Nazli, F.; Wang, X.; Ahmad, M.; Hussain, A.; Bushra; Dar, A.; Nasim, M.; Jamil, M.; Panpluem, N.; Mustafa, A. Efficacy of indole acetic acid and exopolysaccharides-producing Bacillus safensis strain FN13 for inducing Cd-stress tolerance and plant growth promotion in Brassica juncea (L.). Appl. Sci. 2021, 11, 4160. [CrossRef]

28. Olanrewaju, O.; Bernard, G.; Olubukola, B. Mechanisms of action of plant growth promoting bacteria. World J. Microbiol. Biotechnol. 2017, 33, 197. [CrossRef] [PubMed]

29. Mumtaz, M.Z.; Ahmad, M.; Jamil, M.; Hussain, T. Zinc solubilizing Bacillus spp. potential candidates for biofortification in maize. Microbiol. Res. 2017, 202, 51-60. [CrossRef] [PubMed]

30. Ryan, J.; Estefan, G.; Rashid, A. Soil and plant analysis laboratory manual, 2nd ed.; International Center for Agriculture in Dry Areas (ICARDA): Aleppo, Syria, 2001; p. 172.

31. Donkin, M.J. Loss-on-ignition as an estimator of soil organic carbon in a-horizon forestry soils. Commun. Soil Sci. Plant Anal. 1991, 22, 233-241. [CrossRef]

32. Kjeldahl, J. Neue Methode zur Bestimmung des Stickstoffs in organischen Körpern. Z. Für Anal. Chem. 1883, 22, 366-382. [CrossRef]

33. Watanabe, F.S.; Olsen, S.R. Test of an Ascorbic Acid Method for Determining Phosphorus in Water and NaHCO3 Extracts from Soil. Soil Sci. Soc. Am. J. 1965, 29, 677-678. [CrossRef]

34. Ayers, R.S.; Westcot, D.W. Water Quality for Agriculture; Food and Agriculture Organization of the United Nations: Rome, Italy, 1994.

35. Dhindsa, R.S.; Plumb-Dhindsa, P.; Thorpe, T.A. Leaf Senescence: Correlated with Increased Levels of Membrane Permeability and Lipid Peroxidation, and Decreased Levels of Superoxide Dismutase and Catalase. J. Exp. Bot. 1981, 32, 93-101. [CrossRef]

36. Gorin, N.; Heidema, F.T. Peroxidase activity in Golden Delicious apples as a possible parameter of ripening and senescence. J. Agric. Food Chem. 1976, 24, 200-201. [CrossRef]

37. Beauchamp, C.; Fridovich, I. Superoxide dismutase: Improved assays and an assay applicable to acrylamide gels. Anal. Biochem. 1971, 44, 276-287. [CrossRef]

38. Thimmaiah, S.R. Standard methods of biochemical analysis; Kalyani Publishers: New Delhi, India, $2004 ;$ p. 80.

39. Miller, R.O. Nitric-perchloric acid wet digestion in an open vessel. In Handbook of Reference Methods for Plant Analysis; Karla, Y.P., Ed.; CRC Press: Boca Raton, FL, USA, 1998; pp. 57-61. 
40. Steel, R.G.D.; Torrie, J.H.; Dickey, D.A. Principles and Procedures of Statistics. A Biometrical Approach, 3rd ed.; McGraw Hill Book Co.: New York, NY, USA, 2007.

41. Arora, M.; Kiran, B.; Rani, S.; Rani, A.; Kaur, B.; Mittal, N. Heavy metal accumulation in vegetables irrigated with water from different sources. Food Chem. 2008, 111, 811-815. [CrossRef]

42. Huang, S.; Liao, Q.; Hua, M.; Wu, X.; Bi, K.; Yan, C.; Chen, B.; Zhang, X. Survey of heavy metal pollution and assessment of agricultural soil in Yangzhong district, Jiangsu Province, China. Chemosphere 2007, 67, 2148-2155. [CrossRef] [PubMed]

43. Chabukdhara, M.; Munjal, A.; Nema, A.K.; Gupta, S.K.; Kaushal, R.K. Heavy metal contamination in vegetables grown around peri-urban and urban-industrial clusters in Ghaziabad, India. Hum. Ecol. Risk Assess. Int. J. 2015, 22, 1-17. [CrossRef]

44. Abou-Shanab, R.; Angle, J.; Delorme, T.; Chaney, R.; Van Berkum, P.; Moawad, H.; Ghanem, K.; Ghozlan, H. Rhizobacterial effects on nickel extraction from soil and uptake by Alyssum murale. New Phytol. 2003, 158, 219-224. [CrossRef]

45. Saranya, K.; Sundaramanickam, A.; Shekhar, S.; Meena, M.; Sathishkumar, R.S.; Balasubramanian, T. Biosorption of mul-ti-heavy metals by coral associated phosphate solubilising bacteria Cronobacter muytjensii KSCAS2. J. Environ. Manag. 2018, 222, 396-401. [CrossRef]

46. Bilal, S.; Shahzad, R.; Khan, A.L.; Al-Harrasi, A.; Kil Kim, C.; Lee, I.-J. Phytohormones enabled endophytic Penicillium funiculosum LHL06 protects Glycine max L. from synergistic toxicity of heavy metals by hormonal and stress-responsive proteins modulation. J. Hazard. Mater. 2019, 379, 120824. [CrossRef]

47. Rajkumar, M.; Ae, N.; Prasad, M.N.; Freitas, H. Potential of siderophore-producing bacteria for improving heavy metal phytoextraction. Trends Biotechnol. 2010, 28, 142-149. [CrossRef]

48. Gamalero, E.; Glick, B.R. Bacterial Modulation of Plant Ethylene Levels. Plant Physiol. 2015, 169, 13-22. [CrossRef]

49. Nanda, M.; Kumar, V.; Sharma, D.K. Multimetal tolerance mechanisms in bacteria: The resistance strategies acquired by bac-teria that can be exploited to 'clean-up' heavy metal contaminants from water. Aquat. Toxicol. 2019, 212, 1-10. [CrossRef]

50. Mitra, A.; Chatterjee, S.; Kataki, S.; Rastogi, R.P.; Gupta, D.K. Bacterial tolerance strategies against lead toxicity and their rel-evance in bioremediation application. Environ. Sci. Pollut. Res. 2021, 2,1-4.

51. Asghar, H.N.; Ishaq, M.; Zahir, Z.A.; Khalid, M.; Arshad, M. Response of radish to integrated use of nitrogen fertilizer and recycled organic waste. Pak. J. Botany 2006, 38, 691-700.

52. Aafi, N.E.; Brhada, F.; Dary, M.; Maltouf, A.F.; Pajuelo, E. Rhizostabilization of metals in soils using Lupinus luteus inoculated with the metal resistant rhizobacterium Serratia sp. MSMC541. Int. J. Phytoremediation 2012, 14, 261-274. [CrossRef]

53. Chookhampaeng, S. The effect of salt stress on growth, chlorophyll content proline content and antioxidative enzymes of pepper (Capsicum annuum L.) seedling. Eur. J. Sci. Res. 2011, 49, 103-109.

54. Zhai, Q.; Wang, G.; Zhao, J.; Liu, X.; Narbad, A.; Chen, Y.Q.; Zhang, H.; Tian, F.; Chen, W. Protective Effects of Lactobacillus plantarum CCFM8610 against Chronic Cadmium Toxicity in Mice Indicate Routes of Protection besides Intestinal Sequestration. Appl. Environ. Microbiol. 2014, 80, 4063-4071. [CrossRef]

55. Flora, S.J.S.; Mittal, M.; Mehta, A. Heavy metal induced oxidative stress \& its possible reversal by chelation therapy. Indian J. Med. Res. 2008, 128, 501. [PubMed]

56. Janmohammadi, M.; Bihamta, M.; Ghasemzadeh, F. Influence of rhizobacteria inoculation and lead stress on the physiological and biochemical attributes of wheat genotypes. Cercet. Agron. Moldova 2013, 46, 49-67. [CrossRef] 
57. Mesa-Marín, J.; Del-Saz, N.F.; Rodríguez-Llorente, I.D.; Redondo-Gómez, S.; Pajuelo, E.; Ribas-Carbó, M.; Mateos-Naranjo, E. PGPR reduce root respiration and oxidative stress enhancing spartina maritima root growth and heavy metal rhizoaccumula-tion. Front. Plant Sci. A 2018, 17, 1500. [CrossRef]

58. Khanna, K.; Jamwal, V.L.; Gandhi, S.G.; Ohri, P.; Bhardwaj, R. Metal resistant PGPR lowered Cd uptake and expression of metal transporter genes with improved growth and photosynthetic pigments in Lycopersicon esculentum under metal toxicity. Sci. Rep. 2019, 9, 1-4. [CrossRef] [PubMed]

59. Food Additives and Contaminants, Joint Codex Alimentarius Commission; FAO/WHO Food Standards Programme: Rome, Italy, 2001; ALINORM 01/12A. 